\title{
PERAN MODERASI KOMPENSASI DALAM MENJELASKAN PENGARUH BUDAYA ORGANISASI TERHADAP KEPUASAN KERJA (STUDI PADA PT POS INDONESIA PERSERO MAKASSAR TAHUN
} 2019-2020)

\author{
Muh Irgyiansyah ${ }^{1}$, Alimuddin Hadji ${ }^{2}$, Herman Sjahruddin $^{3}$ \\ ${ }^{123)}$ Fakultas Ekonomi Sekolah Tinggi Ilmu Ekonomi Makassar Bongaya, Indonesia \\ E-mail: irgyiansyah@gmail.com ${ }^{1}$, drsalimuddin560@ gmail.com ${ }^{2}, \underline{\text { herman.sjahruddin @ stiem-bongaya.ac.id }{ }^{3}}$
}

\begin{abstract}
Abstrak
Penelitian ini bertujuan untuk menguji dan menganalisis Pengaruh budaya organisasi terhadap kepuasan kerja yang di moderasi dengan kompensasi pada PT. Pos Indonesia (Persero) Makassar. Pengumpulan data menggunakan data primer dengan menggunakan teknik sampel jenuh, Populasinya adalah 100 kuesioner, sedangkan sampel yang diambil berjumlah 70 kuesioner, Hasil data tersebut telah diuji asumsi klasik berupa asumsi normalitas dan heterodaksitas, metode analisis data menggunakan moderated analysis regression (MRA). Hasil penelitian menunjukkan bahwa hipotesis pertama yang diajukan ditolak karena menunjukkan hasil uji hipotesis yang tidak berpengaruh signifikan terhadap kepuasan kerja. Sedangkan hipotesis kedua diterima karena moderasi memperkuat antara Budaya organisasi terhadap Kepuasan kerja. Maka dapat disimpulkan bahwa variabel kompensasi sebagai quasi moderator dapat digunakan sebagai variabel independen sekaligus variabel moderator dalam model (Homologiser Moderator)
\end{abstract}

Kata Kunci : Budaya Organisasi, Kepuasan Kerja, Kompensasi 


\section{PENDAHULUAN}

PT. Pos Indonesia (Persero) dalam menjalankan aktivitas bisnisnya perusahaan dituntut untuk menghasilkan kinerja yang maksimal. Penciptaan kinerja yang maksimal dapat dilakukan jika perusahaan mampu menghasilkan kepuasan kerja yang yang tinggi dan dirasakan oleh karyawan. Kepuasan kerja karyawan berdasarkan teori merujuk pada discrepancy theory atau teori ketidaksesuaian bahwa kepuasan kerja seseorang dapat diperoleh dengan menghitung selisih antara sesuatu yang seharusnya dengan yang dirasakan. Sehingga apabila kepuasan yang diperoleh individu dalam bekerja melebihi dari apa yang mereka inginkan, maka individu tersebut akan merasakan kepuasan dalam bekerja, sehingga terdapat ketidaksesuaian (discrepancy) tetapi ketidaksesuaian (discrepancy) yang positif sebaliknya jika individu tersebut merasakan ketidakpuasan maka individu tersebut akan merasakan adanya ketidaksesuaian (discrepancy) yang sifatnya negatif (Ghozali, I. 2017). Pokok permasalahan dalam penelitian ini bertujuan untuk menganalisis faktor-faktor yang menjadi sumber kepuasan kerja karyawan tetap pada PT POS Indonesia (persero) mengalami perkembangan yang pesat. Bertambahnya jumlah karyawan maka permasalahan sumber daya manusia yang dihadapi perusahaan semakin kompleks, oleh karenanya manajemen sumber daya manusia harus dikelola dengan baik agar menghasilkan sumber daya manusia yang puas dan memuaskan bagi perusahaan.

Berdasarkan pengamatan telah di temukan karyawan yang memiliki masa kerja yang cukup rendah jika di bandingkan dengan karyawan lainya memperoleh besaran insentif yang jumlahnya jauh lebih besar di bandingkan karyawan yang bekerja dengan pekerjaan yang sama namun diberikan insentif yang lebih rendah.

maka salah satu faktor yang mempengaruhi kepuasan kerja karyawan adalah faktor hubungan antar karyawan (hubungan antar manajer dan karyawan, hubungan sosial antara sesama karyawan, sugesti dari teman sekerja, faktor fisik dan kondisi tempat kerja, emosi dan situasi kerja). Dalam penelitian ini, faktor tersebut dinyatakan sebagai faktor budaya organisasi. PT. Pos Indonesia (Persero) yaitu perusahaan jasa milik pemerintah yang bergerak khusus untuk memberikan pelayanan kepada seluruh masyarakat terhadap pengiriman barang sebagai ujung tombak perusahaan, karyawan dituntut untuk bekerja dengan maksimal agar layanan prima dapat tercapai bagi masyarakat. menyadari hal tersebut perusahaan dipandang perlu untuk memperhatikan kepuasan kerja karyawan dan berupaya meningkatkan budaya organisasi dengan adanya kompensasi.
Beberapa peneliti terdahulu menganalisis pengaruh budaya organisasi terhadap kepuasan kerja memperoleh hasil yang berbeda, bahwa budaya organisasi yang diukur dengan inisiatif individu, pengarahan, integrasi, kontrol, imbalan dan pola komunikasi berpengaruh positif signifikan terhadap kepuasan kerja (Rifdah Abadiyah dan Didik Purwanto, 2016). Peneliti lainnya (Parimitawidya dkk., 2013), budaya organiasi berpengaruh negatif tidak signifikan terhadap kepuasan kerja (Okii kurnia dan S.Pantja Djati, 2017).

Kompensasi adalah semua pendapatan yang berbentuk uang, barang langsung atau tidak langsung yang diterima pegawai sebagai imbalan atas jasa yang diberikan kepada organisasi. Tujuan pemberian kompensasi antara lain adalah sebagai ikatan kerja sama, kepuasan kerja, pengadaan efektif, motivasi, stabilitas pegawai, dan disiplin. (Marpaung, Suruan, \& Papua, 2019).

Apabila sistem kompensasi tersebut sudah memenuhi kebutuhan para pegawai, maka mereka akan senantiasa memenuhi kewajiban mereka dengan bekerja secara optimal. Terpenuhnya kompensasi dan pemberian motivasi yang baik tentu saja akan meningkatkan produktivitas serta kepuasan kerja parah karyawan.

\section{TINJAUAN PUSTAKA}

\section{Budaya organisasi}

Budaya organisasi seringkali digambarkan dalam arti yang dimiliki bersama. Pola-pola dari kepercayaan, simbol-simbol, ritual-ritual dan mitos mitos yang berkembang dari waktu ke waktu dan berfungsi sebagai perekat yang menyatukan organisasi. Beraneka ragamnya bentuk organisasi atau perusahaan, tentunya mempunyai budaya yang berbeda-beda hal ini wajar karena lingkungan organisasinya berbedabeda pula misalnya perusahaan jasa, manufaktur dan trading (Koesmono, H. T. 2011).

Budaya organisasi adalah merupakan suatu persepsi bersamayang dianut oleh anggotaanggota organisasi itu, budaya organisasi menyangkutbagaimana para anggota melihat organisasi tersebut, bukan menyangkut apakahpara anggota organisasi menyukainya atau tidak, karena para anggota menyerapbudaya organisasi berdasarkan dari apa yang mereka lihat atau dengar di dalamorganisasi. Anggota organisasi cenderung mempersepsikan sama tentangbudaya dalam organisasi tersebut meskipun mereka berasal dari latar belakangyang berbeda ataupun bekerja pada tingkat-tingkat keahlian yang berlainan dalamorganisasi tersebut (Nasution, R. S. 2018).

Menurut pendapat para ahli, indikator yang dapat mempengaruhi budaya organisasi adalah sebagai berikut (Kartikasari, L. 2017): 
a. Perilaku pemimpin tindakan nyata dari seorang pemimpin biasanya akan menjadi cermin penting bagi para pegawai.

b. Mengedepankan misi perusahaan jika tujuan suatu organisasi sudah ditetapkan, setiap pemimpin harus dapat memastikan bahwa misi tersebut harus berjalan.

c. Proses pembelajaran pembelajaran pegawai harus tetap berlanjut. Untuk menghasilkan budaya kerja yang sesuai, para pegawai membutuhkan pengembangan keahlian dan pengetahuan.

d. Motivasi pekerja membutuhkan dorongan untuk turut memecahkan masalah organisasi lebih inovatif.

\section{Kepuasan kerja}

Kepuasan kerja adalah sikap umum

terhadap pekerjaan seseorang, yang menunjukkan perbedaan antara jumlah penghargaan yang mereka diterima pekerja dan jumlah yang mereka yakini seharusnya mereka terima. Kepuasan kerja merupakan suatu cara pandang seseorang baik yang bersifat positif maupun bersifat negative tentang pekerjaannya (Sajangbati, I. A. 2013).

Kepuasan kerja karyawan berdasarkan teori merujuk pada discrepancy theory atau teori ketidaksesuaian bahwa kepuasan kerja seseorang dapat diperoleh dengan menghitung selisih antara sesuatu yang seharusnya dengan yang dirasakan. Sehingga apabila kepuasan yang diperoleh individu dalam bekerja melebihi dari apa yang mereka inginkan, maka individu tersebut akan merasakan kepuasan dalam bekerja, sehingga terdapat ketidaksesuaian (discrepancy) tetapi ketidaksesuaian (discrepancy) yang positif sebaliknya jika individu tersebut merasakan ketidakpuasan maka individu tersebut akan merasakan adanya ketidaksesuaian (discrepancy) yang sifatnya negatif. (Locke 1960 dalam Winarsih dkk. 2019).

Indikator Kepuasan Kerja Menurut (Simamora, F., Machasin, M., \& Restuti, S. 2015) (Ikmal nur Muflih Ekonomi \& Yogyakarta, 2015) indikator dari kepuasan kerja terdiri dari :

a. Isi pekerjaan penampilan tugas atau atribut pekerjaan yang aktual dan sebagai kontrol terhadap pekerjaan. Karyawan akan merasa puas apabila tugas kerja dianggap menarik dan memberikan kesempatan belajar dan mendapat kepercayaan tanggung jawab atas pekerjaan itu.

b. Supervisi perhatian dan hubungan yang baik dari pimpinan kepada bawahan, sehingga karyawan akan merasa bahwa
NIAGAWAN Vol 9 No 1 Maret 2020

dirinya menjadi bagian yang penting dari organisasi. Sebaliknya, supervisi yang buruk dapat meningkatkan turn over dan absensi karyawan.

c. Organisasi dan manajemen perusahaan dan manajemen yang baik adalah yang mampu memberikan situasi dan kondisi kerja yang stabil, untuk memberikan kepuasan kepada karyawan.

d. Kesempatan untuk maju adanya kesempatan untuk memperoleh pengalaman dan peningkatan kemampuan selama bekerja akan memberikan kepuasan pada karyawan terhadap pekerjaannya.

e. Rekan kerja adanya hubungan yang dirasa saling mendukung dan saling memperhatikan antar rekan kerja akan menciptakan lingkungan kerja yang nyaman dan hangat sehingga menimbulkan kepuasan kerja pada karyawan.

f. Kondisi pekerjaan kondisi kerja yang mendukung akan meningkatkan kepuasan kerja pada karyawan. Kondisi kerja yang mendukung artinya tersedianya sarana dan prasarana kerja yang memadai sesuai dengan sifat tugas yang harus diselesaikannya.

\section{Kompensasi}

Setiap orang pada dasarnya bekerja ingin memperoleh uang untuk memenuhi kebutuhan hidupnya. Seorang karyawan yang bekerja pada suatu perusahaan akan bekerja keras dan semakin menunjukkan loyalitas terhadap perusahaan untuk memperoleh imbalan sesuai yang diinginkan dan karena itulah perusahaan memberikan balas jasa atas kinerja karyawan tersebut terhadap perusahaan yaitu dengan jalan memberikan kompensasi. Salah satu cara manajemen untuk meningkatkan prestasi kerja, memotivasi dan meningkatkan kinerja para karyawan adalah melalui kompensasi (Mathis dan Jackson, 2001).

Indikator kompensasi (Anwari, 2018) yaitu:

a. Gaji adalah imbalan finansial yang dibayarkan kepada karyawan secara teratur, seperti tahunan, caturwulan, bulanan atau mingguan, atau, dapat juga dikatakan sebagai bayaran tetap yang diterima seseorang dari keanggotaannya dalam sebuah perusahaan.

b. Bonus merupakan imbalan langsung yang dibayarkan kepada karyawan karena kinerjanya melebihi standar yang ditentukan.Bonus merupakan bentuk lain dari upah langsung di luar upah dan gaji yang merupakan kompensasi tetap, yang biasa disebut kompensasi berdasarkan kinerja (pay for performance plan). 
Tunjangan Pemberian tunjangan kepada karyawan berupa uang atau barang, namun sifatnya tertentu saja. Tunjangan diberikan kepada karyawan yang telah diangkat menjadi pegawai tetap, seperti tunjangan hari raya, asuransi kesehatan, dan sebagainya.

\section{METODE PENELITIAN}

Metode penelitian pada dasarnya adalah cara ilmiah untuk mendapatkan data dengan tujuan dan kegunaan tertentu. jenis penelitian yang di gunakan dalam penelitian ini adalah pendekatan kuantitatif dengan penelitian deskriptif. Penelitian kuantitatif adalah penelitian dengan metode statistik untuk menguji hipotesis. Penelitian deskriptif adalah suatu metode dalam meneliti status kelompok manusia, suatu objek, suatu set kondisi, suatu system pemikiran ataupun suatu kelas peristiwa pada masa yang akan datang, tujuannnya adalah untuk membuat deskripsi atau gambaran sistematis dan akurat mengenai fakta-fakta yang terjadi. (Sugiono 2017: 2)

Metode analisis data dalam penelitian ini yaitu melalui uji statistik deskriptif variabel, uji asumsi klasik, uji koefisien determinasi, uji regresi sederhana, uji regresi moderasi, uji kelayakan model (uji F), dan uji koefisien regresi parsial (uji $\mathrm{T}$ ). Pengujian dilakukan melalui SPSS versi 25.

Berdasarkan metode analisis tersebut, hipotesis (Ha) yang akan diuji yaitu:

Ha1: Budaya Organisasi Berpengaruh Terhadap Kepuasan Kerja

Ha2: Kompensasi Memperkuat Hubungan Antara Budaya Organisasi Terhadap Kepuasan Kerja.

\section{Tempat dan Waktu}

Objek Penelitian ini akan di lakukan pada PT. POS INDONESIA dan pengambilan data dilakukan pada kantor PT. POS (Persero) PUSAT MAKASSAR, yang beralamat jln, Selamet Riyadi No. 10, Bulo Gading, Kec. Ujung Pandang, Kota Makassar, Sulawesi Selatan 90111. Adapun waktu penelitian ini akan dilaksanakan selama 2 (Satu) bulan yakni dari awal bulan November 2019 hingga akhir bulan Desember 2019.

\section{Populasi dan Sampel}

Populasi

Populasi adalah wilayah generalisasi yang terdiri atas : obyek/subyek yang mempunyai kualitas dan karakteristik tertentu yang di tetapkan oleh peneliti untuk di pelajari dan kemudian di tarik kesimpulannya, Sugiyono (2017: 80). Dalam penelitian ini populasi yang di ambil adalah seluruh pegawai kantor PT POS INDONESIA (persero) Makassar yang berjumlah kurang lebih 70 orang.

\section{Sampel}

Sampel adalah bagian dari jumlah dan karakteristik yang di miliki oleh populasi tersebut, Sugiyono (2017: 81). Sampel yang di ambil adalah seluruh pegawai kantor PT POS INDONESIA (Persero) Makassar, dengan menggunakan metode sampel di mana beberapa dari setiap anggota populasi di pilih menjadi sampel. Dari penelitian ini di ambil populasi berjumlah 70 pegawai dari 100 jumlah keseluruhan pegawai.

\section{Metode Analisis}

Analisis merupakan sebuah proses berkelanjutan dalam penelitian, dengan analisis awal mengimformasikan data yang kemudian dikumpulkan. Ketika peneliti sudah selesai dalam mengumplkan data, maka langkah berikutnya ialah menganlisis data yang telah diperoleh. Berikut ini merupakan analisis yang dipakai penulis:

\section{Analisis Statistik Deskriptif}

Analisisis statistic deskriptif dalam penelitian pada dasarnya merupakan proses informasi data penelitian dalam bentuk tabulasi, sehingga muda dipahami dan mudah diinterprestasikan. Tabulasi menyajikan ringkasan pengaturan atau penyusunan data dalam bentuk table numeric.

Menurut mudrajat (2013: 81) statistic deskriptif yaitu statistic yang digunakan untuk menganalisis data dengan cara mendeskripsikan atau menggambarkan data yang telah terkumpul sebagaimana adanya tanpa bermaksud membuat kesimpulan yang berlaku untuk umum atau generalisasi. Analisis deskriptif dalam penelitian ini menjelaskan karakteristik respnden dan tanggapan responden terhadap variable penelitian.

\section{Moderated Regression Analysis (MRA)}

Moderated Regression Analysis (MRA) atau uji interaksi merupakan aplikasi khusus regresi berganda linear yang didalamnya ada persamaan regresi dengan unsur interaksi (perkalian dua atau lebih variabel independen).

Dalam penelitian ini yang menjadi variable dependen adalah kepuasan kerja (Y), variable independen adalah budaya organisasi (X1) , dan Kompensasi (M) sebagai variable pemoderasi.

Persamaan MRA adalah sebagai berikut (Ghozali, 2011).

$$
\mathrm{Y}=\alpha+\beta 1 \mathrm{X} 1+\beta 2 \mathrm{M}+\beta 3 \mathrm{X} 1 * \mathrm{M}+
$$

$\mathrm{e}$

Keterangan :

$\mathrm{Y} \quad=$ Kepuasan kerja

$\beta \times 1=$ Budaya organisasi

$\beta \mathrm{M}=$ Kompensasi 
NIAGAWAN Vol 9 No 1 Maret 2020

$\beta \mathrm{X} 1 * \mathrm{M}=$ Interaksi antara budaya organisasi dengan kompensasi

$\beta 1-\beta 3=$ Koefisien regresi

a $=$ Nilai konstanta

e $\quad=$ Standard error

Gambar 1 Jenis Variabel Moderasi

\begin{tabular}{|c|l|l|}
\hline $\begin{array}{c}\text { Interaksi antara variabel } \\
\text { moderator dan predictor } \\
(\mathbf{X} \mathbf{Z})\end{array}$ & $\begin{array}{l}\text { Hubungan antara } \\
\text { Variabel Kriteria }\end{array}$ \\
\cline { 2 - 3 } Ada Interaksi & \multicolumn{1}{|c|}{$\mathbf{Y}=\mathbf{f}(\mathbf{X}, \mathbf{Z})$} \\
\hline \multirow{2}{*}{ Tida Hubungan } & \multicolumn{1}{|c|}{ Tidak Ada Hubungan } \\
\hline $\begin{array}{l}\text { exogeneous, } \\
\text { antecedent atau } \\
\text { Prediktor }\end{array}$ & (1) Homologizer Moderator \\
\hline & $\begin{array}{l}\text { (4) Quasi } \\
\text { Moderator }\end{array}$ & (3) Pure Moderator \\
\hline
\end{tabular}

Sumber: Sugiono (2004).

\section{Koefisien Determinasi (R2)}

Koefisien determinasi (R2) dimaksudkan untuk mengetahui tingkat ketepatan yang paling baik dalam analisis regresi, dimana halnya yang ditunjukkan oleh besarnya koefisisen determinasi (R2) antara 0 (nol) dan 1 (satu) . koefisien determinasi (R2) nol, berarti variable independen sama sekali tidak berpengaruh terhadap variable dependen. Apabila koefisien determinasi medekati angka satu, maka dapat dikatakan bahwa variable independen berpengaruh terhadap variable dependen. Selain itu, koefisien determinasi (R2) dipergunkan untuk mengetahui persentase perubahan variable dependen (Y) yang disebabkan oleh variable independen $(\mathrm{X})$.

Pengujian koefisien determinasi dilakukan dengan cara mengalikan nilai koefisien korelasi dengan nilai koefisien regresi yang telah distandarisasi (standardized) beta. sehingga dapat diperoleh besaran kontribusi dari masingmasing variable independen terhadap variable dependen.

\section{HASIL DAN PEMBAHASAN}

Uji asumsi klasik

Uji normalitas

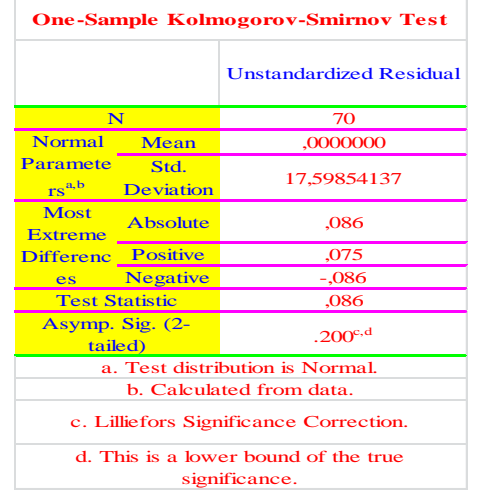

Dari hasil Uji Normalitas diatas diketahui bahwa nilai signifikansi dari uji Kolmogorov-Smirnov sebesar 0.200>0.05 ( $\mathrm{p}>0.05)$, sehingga dapat disimpulkan bahwa data yang di uji terdistribusi normal

\section{Uji Heterokedastisitas}

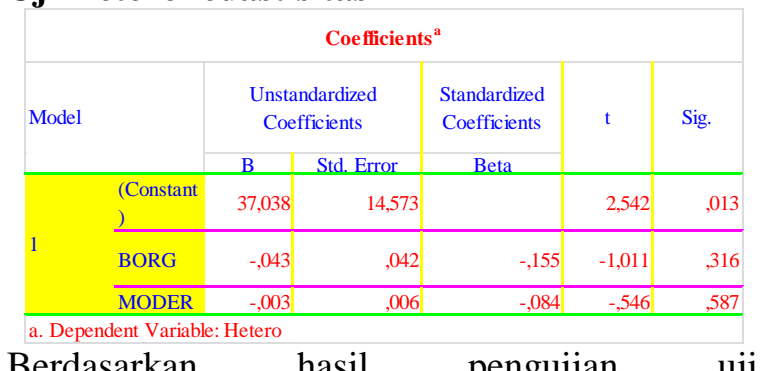

Berdasarkan hasil pengujian uji heterokedastisitas pada table 4.8 menunjukkan bahwa independen yaitu BORG memiliki nilai signifikan $0.316>0.05$, variable pemoderasi yaitu KOMP memiliki nilai signifikan 0.587>0.05. Berdasarkan hasil tersebut maka dapat disimpulkan bahwa data dalam penelitian ini tidak terdapat nilai heterokedastisitas yang terlihat dari nilai signifikan $>0.05$.

\section{Hasil Analisis Statistik Deskriptif}

\begin{tabular}{|c|c|c|c|c|c|}
\hline & Minimum & Maximum & Mean & $\begin{array}{c}\text { Std. } \\
\text { Deviation }\end{array}$ & $\mathrm{N}$ \\
\hline $\begin{array}{l}\text { Predicted } \\
\text { Value }\end{array}$ & 327,0540 & 497,0236 & 413,9143 & 35,48986 & 70 \\
\hline $\begin{array}{l}\text { Std. } \\
\text { Predicted } \\
\text { Value }\end{array}$ & $-2,447$ & 2,342 &, 000 & 1,000 & 70 \\
\hline $\begin{array}{l}\text { Standard } \\
\text { Error of } \\
\text { Predicted } \\
\text { Value }\end{array}$ & 2,140 & 6,680 & 3,586 & ,905 & 70 \\
\hline $\begin{array}{l}\text { Adjusted } \\
\text { Predicted } \\
\text { Volue } \\
\end{array}$ & 324,2979 & 497,3409 & 413,9116 & 35,64348 & 70 \\
\hline Residual & $-48,13234$ & 34,05553 &, 00000 & 17,59854 & 70 \\
\hline Std. & $-2,695$ & 1,907 &, 000 &, 985 & 70 \\
\hline $\begin{array}{l}\text { Stud. } \\
\text { Residual }\end{array}$ & $-2,737$ & 1,929 &, 000 & 1,004 & 70 \\
\hline $\begin{array}{l}\text { Deleted } \\
\text { Residual } \\
\end{array}$ & $-49,64601$ & 34,84163 & ,00271 & 18,27413 & 70 \\
\hline $\begin{array}{l}\text { Stud. } \\
\text { Deleted } \\
\text { Residual }\end{array}$ & $-2,883$ & 1,970 &,- 004 & 1,022 & 70 \\
\hline $\begin{array}{l}\text { Mahal. } \\
\text { Distance }\end{array}$ & ,005 & 8,667 & 1,971 & 1,669 & 70 \\
\hline $\begin{array}{l}\text { Cook's } \\
\text { Distance }\end{array}$ & ,000 & ,111 & ,013 & ,021 & 70 \\
\hline $\begin{array}{l}\text { Centered } \\
\text { Leverage } \\
\text { Value }\end{array}$ & ,000 & , 126 & ,029 & ,024 & 70 \\
\hline
\end{tabular}

Tabel diatas menunjukkan ada 70 sampel yang digunakan dengan nilai minimum 327,0540 nilai maksimum sebesar 497,0236, nilai rata-rata atau mean sebesar 413.9143 dan standard deviation sebesar 35,48966.

Hasil Moderated Analysis Regression (MRA)

\begin{tabular}{|c|c|c|c|c|c|c|}
\hline \multicolumn{7}{|c|}{ Coefficients $^{\mathrm{a}}$} \\
\hline \multirow[t]{2}{*}{ Model } & & \multicolumn{2}{|c|}{$\begin{array}{l}\text { Unstandardized } \\
\text { Coefficients }\end{array}$} & \multirow{2}{*}{$\begin{array}{c}\text { Standardized } \\
\text { Coefficients } \\
\text { Beta } \\
\end{array}$} & \multirow[t]{2}{*}{$\mathrm{T}$} & \multirow[t]{2}{*}{ Sig. } \\
\hline & & B & Std. Error & & & \\
\hline \multirow{3}{*}{1} & $\begin{array}{l}\text { (Constant } \\
\end{array}$ & 207,959 & 22,920 & & 9,073 & 000 \\
\hline & BORG & ,058 & ,067 & 061 &, 872 &, 386 \\
\hline & $\begin{array}{l}\text { MODER } \\
\text { ASI }\end{array}$ & 106 & ,009, & ,856 & 12,241 & 000 \\
\hline
\end{tabular}

a. Dependent Variable: KPKE

Pengaruh BORG melalui Total KOMPENSASI terhadap KPKE diketahui 
pengaruh langsung sebesar, 061 sedangkan pengaruh tidak langsung BORG melalui Total KOMPENSASI terhadap KPKE ialah perkalian antara nilai beta BORG terhadap Nilai Total KOMPENSASI dengan nilai beta Total KOMPENSASI terhadap KPKE yaitu 0,67 $\mathrm{x}$ $0,856=0,573$ maka total pengaruh yang diberikan BORG terhadap KPKE adalah pengaruh langsung ditambah pengaruh tidak langsung yaitu $0.61+0,573=1,183$. Berdasarkan hasil perhitungan diketahui pengaruh langsung sebesar 0.61 dan pengaruh tidak langsung sebesar 1,183 hasil ini menunjukkan bahwa secara tidak langsung BORG melalui Total KOMPENSASI mempunyai pengaruh terhadap KPKE.

\section{Hasil Uji Hipotesis}

Uji $F$ digunakan untuk mengetahui apakah variabel-variabel independen secara simultan berpengaruh signifikan terhadap variabel dependen. Derajat kepercayaan yang digunakan adalah 0,05 . Apabila nilai $F$ hitung hasil perhitungan lebih besar daripada nilai $\mathrm{F}$ tabel menurut tabel maka hipotesis alternatif yang menyatakan bahwa semua variabel independen secara simultan berpengaruh signifikan terhadap variabel dependen. untuk analisisnya dari output SPSS 25 dapat dilhat dari gambar berikut :

\begin{tabular}{|c|c|c|c|c|c|c|}
\hline \multicolumn{7}{|c|}{ ANOVA $^{a}$} \\
\hline Model & & $\begin{array}{c}\text { Sum of } \\
\text { Squares }\end{array}$ & Df & Mean Square & F & Sig. \\
\hline \multirow{3}{*}{1} & Regression & 86907,588 & 2 & 43453,794 & 136,239 & $.000^{\mathrm{b}}$ \\
\hline & Residual & 21369,897 & 67 & 318,954 & & \\
\hline & Total & 08277,486 & 69 & & & \\
\hline \multicolumn{7}{|c|}{ a. Dependent Variable: KPKE } \\
\hline b. Predi & ors: (Constant & MODERA: & ORG & & & \\
\hline
\end{tabular}

Dari tabel 4.11 Pengujian secara simultan $\mathrm{X}, \mathrm{M}$ terhadap $\mathrm{Y}$ : dari gambar diperoleh nilai $\mathrm{F}$ hitung sebesar 136.239 dengan nilai probabilitas $(\mathrm{sig})=0,000$. Nilai $\mathrm{F}$ hitung $(136.239)>$ F tabel $(3,1337)$ dan sig lebih kecil dari nilai probabilitas 0,05 atau nilai $0,000<$ 0,05 , sehingga dapat di simpulkan bahwa model yang di gunakan dalam penelitian ini terbukti memenuhi pengujian kesesuaian model sehingga dapat di lanjutkan untuk di analisis.

\section{Hasil Uji t}

Uji parsial digunakan untuk menunjukkan seberapa jauh suatu variabel independen secara individual dalam menerangkan variabel dependen. Tingkat signifikan dalam penelitian ini adalah 5\%. Dimana jika angka probabilitas signifikansi > 5\% maka $\mathrm{H0}$ ditolak, jika angka probabilitas signifikansi $\leq 5 \%$ maka $\mathrm{H} 0$ diterima.
NIAGAWAN Vol 9 No 1 Maret 2020

\begin{tabular}{|c|c|c|c|c|c|c|c|c|}
\hline \multicolumn{9}{|c|}{ Coefficients $^{\mathrm{a}}$} \\
\hline \multirow{2}{*}{ Mode } & & \multicolumn{2}{|c|}{$\begin{array}{l}\text { Unstandardized } \\
\text { Coefficients }\end{array}$} & \multirow{2}{*}{$\begin{array}{c}\text { Standardized } \\
\text { Coefficients } \\
\text { Beta }\end{array}$} & \multirow{2}{*}{$t$} & \multirow{2}{*}{ Sig. } & \multicolumn{2}{|c|}{$\begin{array}{l}\text { Collinearity } \\
\text { Statistics }\end{array}$} \\
\hline & & B & Std. Error & & & & Tolerance & VIF \\
\hline \multirow{3}{*}{1} & (Constant) & 207,959 & 22,920 & & 9,073 & , 000 & & \\
\hline & BORG & ,058 & 067 & ,061 &, 872 & .386 & ,602 & 1,661 \\
\hline & MODERASI & ,106 & ,009 & 856 & 12,241 & ,000 & ,602 & 1,661 \\
\hline
\end{tabular}

Berdasarkan hasil uji parsial tabel di atas dapat diketahui pengaruh masing-masing variabel independen yang terdiri atas Budaya Organisasi terhadap variabel dependen yaitu Kepuasan Kerja yang akan dijelaskan sebagai berikut :

Hasil uji persial tentang Budaya Organisasi (X) terhadap Kepuasan Kerja di tolak , hal ini diperoleh dari hasil analisis regresi yaitu t-hitung $\mathrm{X}=0,872$ dan t-tabel $=1.995$. Tampak bahwa untuk variabel $\mathrm{X}$, t-hitung < t-tabel. Dan nilai signifikansi $\mathrm{X}$ sebesar 0,386 atau berada diantara nilai $0,000<0,05$ (taraf nyata $5 \%$ ), maka dapat disimpulkan bahwa Budaya organisasi (X) secara parsial berpengaruh dan signifikan terhadap Kepuasan kerja atau dengan kata lain hasil dari Hipotesis ditolak sehingga dapat di simpulkan bahwa $\mathrm{H}_{\mathrm{a}}$ ditolak dan $\mathrm{H}_{\mathrm{o}}$ diterima Uji parsial variable interaksi antara Kompensasi (KOMP,M) dan Budaya organisasi (BORG,X) Terhadap Kepuasan kerja (KPKE,Y). pada tabel 4.13 diperoleh nilai t-hitung sebesar 12.241 dengan nilai signifikan 0.000 , sehingga dapt disimpulkan bahwa nilai t-hitung > t-tabel $(12.241>1.995$.) dan nilai signifikan lebih kecil dari $0.05(0.000<0.05)$ maka $_{\mathrm{a}}$ di terima dan $\mathrm{H}_{\mathrm{o}}$ di tolak. Maka hipotesis dalam penelitian ini di terimah, bahwa secara parsial interaksi antara budaya organisasi dengan kompensasi $\left(\mathrm{X}^{*} \mathrm{M}\right)$ berpengaruh positif dan signifikan terhadap kepuasan kerja di Perusahaan PT. Pos Indonesia (Persero) Makassar.

Dari hasil uji parsial diatas dapat ditarik kesimpulan $\mathrm{H} 1$ ditolak dan $\mathrm{H} 2$ diterima ini menunjukkan bahwa budaya organisasi tidak berpengaruh positif sedangkan interaksi antara pengaruh budaya organisasi terhadap kepuasan kerja $\left(\mathrm{X}^{*} \mathrm{Y}\right)$ di perkuat oleh kompensasi.

\section{Uji Determinasi ( R2 )}

Uji determinasi bertujuan untuk mengukur seberapa jauh kemampuan model dapat menjelaskan total pengaruh variable-variabel independen. Dalam pengujian hipotesis koefisien determinasi dilihat dari besarnya nilai R-Square (R2), Untuk mengetahui seberapa jauh variable independen likuiditas terhadap kinerja keuangan dimoderasi profitabilitas. Nilai R2 mempunyai interval 0 sampai $1(0 \leq \mathrm{R} 2 \leq 1)$. Jika R2 bernilai besar (mendekati 1) berarti variable independen dapat memberikan hampir semua informasi yang dibuthkan untuk memprediksi variable dependen. Sedangkan jika 
R2 bernilai kecil berarti kemampuan variable bebas dalam menjelaskan variable dependen sangat terbatas.

\begin{tabular}{|l|c|c|c|c|}
\hline \multicolumn{9}{|c|}{ Model Summary } \\
\hline Model & R & R Square & $\begin{array}{c}\text { Adjusted R } \\
\text { Square }\end{array}$ & $\begin{array}{c}\text { Std. Error } \\
\text { of the } \\
\text { Estimate }\end{array}$ \\
\hline 1 & $.218^{\mathrm{a}}$ &, 048 &, 019 & 11,35498 \\
\hline a. Predictors: (Constant), MODERASI, BORG & & \\
\hline
\end{tabular}

Berdasarkan tabel diatas, maka dapat disimpulkan bahwa nila $\mathrm{R}^{2}$ sebesar 0.048 menunjukkan bahwa pengaruh variable independen yaitu (BORG, X) variable pemoderasi yaitu (KOMPS,M) terhadap (KPKE,Y) sebesar $048 \%$ sedangkan sisanya $52 \%$ dipengaruhi oleh factor lain yang tidak dijelaskan dalam penelitian ini.

\section{Pengaruh Budaya Organisasi Terhadap Kepuasan Kerja}

Budaya organisasi adalah merupakan suatu persepsi bersemayang dianut oleh anggotaanggota organisasi itu, budaya organisasi menyangkut bagaimana para anggota melihat organisasi tersebut, bukan menyangkut apakah para anggota organisasi menyukainya atau tidak, karena para anggota menyerapbudaya organisasi berdasarkan dari apa yang mereka lihat atau dengar di dalamorganisasi

Berdasarkan hasil pengujian secara parsial dalam penelitian ini menunjukkan bahwa Budaya organisasi (X) berpengaruh negative dan signifikan terhadap Kepuasan kerja. Dapat dikatakan bahwa hasil penelitian ini mengindikasikan bahwa Budaya organisasi memiliki pengaruh yang lemah namun mampu memberikan kontribusi yang signifikan terhadap tingginya Kepuasan kerja .

Hasil penelitian ini tidak sejalan dengan penelitian yang dilakukan oleh (Parimitawidya dkk., 2013),(Okii kurnia dan S.Pantja Djati 2017) bahwa secara parsial budaya organisasi berpengaruh negatif tidak signifikan terhadap kepuasan kerja.

\section{Kompensasi Memperkuat Hubungan Antara Budaya Organisasi Terhadap Kepuasan Kerja.}

Berdasarkan hasil pengujian secara parsial dalam penelitian ini menunjukkan bahwa interaksi antara budaya organisasi dengan kepuasan kerja $\left(\mathrm{X}^{*} \mathrm{Y}\right)$ di perkuat oleh kompensasi. Hal ini dapat membuktikan bahwa Kompensasi (M) dapat berperan sebagai moderator dalam pengaruh Budaya organisasi terhadap Kepuasan kerja. Artinya, dalam penelitian ini variable BORG (X) tidak boleh langsung ke variable KPKE (Y) tetapi dengan adanya variable KOMP (M) sebagai variable pemoderasi maka akan memberikan pengaruh yang lebih tinggi terhadap Kepuasan kerja pada perusahaan. Hal ini menunjukkan bahwa dengan
NIAGAWAN Vol 9 No 1 Maret 2020 adanya variable Moderasi maka dapat memperkuat pengaruh Budaya organisasi terhadap kepuasan kerja pada perusahaan PT. Pos Indonesia (Persero) Makassar.

Hasil penelitian ini di sejalan dengan penelitian yang dilakukan oleh (Kriswanti 2017) dalam (Hasibuan 2002). Bahwa secara parsial pengaruh budaya organisasi terhadap kepuasan kerja di perkuat oleh Kompensasi

\section{KESIMPULAN DAN SARAN}

Dalam penelitian ini menguji apakah Pengaruh Budaya Organisasi Terhadap Kepuasan Kerja Yang Di Moderasi Dengan Kompensasi. Adapun hasil penelitian mengindikasikan beberapa hal yang menjadi jawaban dari rumusan masalah maupun hipotesis yang diajukan di bab sebelumnya, diantaranya: Pengujian awal Hasil penelitian tentang Budaya Organisasi Terhadap Kepuasan Kerja ditolak, hal ini diperoleh dari hasil analisis regresi yaitu bahwa Budaya organisasi secara parsial tidak berpengaruh dan signifikan terhadap Kepuasan Kerja atau dengan kata lain hasil dari Hipotesis ditolak. Pengujian kedua Kompensasi memperkuat Budaya Organisasi Terhadap Kepuasan Kerja diterima hal ini diperoleh dari hasil analisis regresi sehingga kompensasi dapat memperkuat antara Budaya Organisasi dengan Kepuasan Kerja dengan kata lain hipotesis tersebut di terima.

\section{REFERENSI}

Anwari, Misbakhul. (2018). No Title (September), 160-164.Pengaruh Kompensasi Terhadap Kepuasan Kerja

Muflih, I. N. (2015). Pengaruh Kompensasi dan Motivasi Kerja terhadap Kepuasan Kerja Karyawan. Skripsi dipublikasikan, Fakultas Ekonomi Universitas Negeri Yogyakarta.

Marpaung, A., Suruan, T. M., \& Papua, U. (2019). Pengaruh Kompensasi Dan Pengembangan Karir Terhadap Kinerja Pegawai Negeri Sipil Di Dinas Perhubungan Provinsi Papua Barat.

Sholikhah, S., Simanjuntak, A. S., \& Parimita, W. (2018). Pengaruh Pengembangan Karir, Motivasi Dan Budaya Organisasi Terhadap Kepuasan Kerja Pada Karyawan Perum Perumnas Kantor Pusat Jakarta Timur. Jrmsi - Jurnal Riset Manajemen Sains Indonesia, 9(2), 299-319. Https://Doi.Org/10.21009/Jrmsi.009.2.07

Rosyidah, E., Fadah, I., \& Tobing, D. S. K. (2018). Pengaruh Kepuasan Kerja Dan Budaya Organisasi Terhadap Kinerja Pegawai Melalui Komitmen Organisasi Di Unit-Unit Pelayanan Publik Kabupaten Jember. Jurnal Relasi Stie Mandala 
Jember, 14(1), 1-16. Retrieved From

Http://Jurnal.Stie-

Mandala.Ac.Id/Index.Php/Relasi/Article/Vi ew/246

Mega Nur Asofa, Arif Partono Prasetio, 2018 Analisis Dampak Stres Terhadap Kepuasan Kerja Pada Karyawan Witel Yogyakarta

Mokodompit, W. (2016). Pengaruh Budaya Organisasi Dan Kepuasan Kerja Terhadap Kinerja Karyawan Pt. Pos Indonesia (Persero)Cabang Makassar.122

Abadiyah, R. (2016). Pengaruh Budaya Organisasi, Kompensasi Terhadap Kepuasan Kerja Dan Kinerja Pegawai Bank di Surabaya. JBMP (Jurnal Bisnis, Manajemen dan Perbankan), 2(1), 49-66.

Sajangbati, I. A. (2013). Motivasi, disiplin, dan kepuasan pengaruhnya terhadap kinerja pegawai pt. Pos Indonesia (persero) cabang Bitung. Jurnal EMBA: Jurnal Riset Ekonomi, Manajemen, Bisnis dan Akuntansi, 1(4).

Simamora, F., Machasin, M., \& Restuti, S. (2015). Pengaruh Pelatihan dan Kepuasan Kerja terhadap Semangat Kerja Karyawan pada Perum Pegadaian Kantor Wilayah Pekanbaru. Jurnal Online Mahasiswa Fakultas Ekonomi Universitas Riau, 2(1).

Kartikasari, L. (2017). Dampak Budaya Organisasi Dan Turnover Terhadap Kinerja Karyawan Pada Koperasi Syariah Bmt Itqan Bandung (Doctoral Dissertation, Universitas Widyatama).

Nasution, R. S. (2018). Hubungan Budaya Organisasi dengan Loyalitas Pelayan Kesehatan Dinas Kesehatan Tapanuli Selatan.

Koesmono, H. T. (2011). Pengaruh Budaya Organisasi dan Kepemimpinan terhadap Kinerja Melalui Variabel Mediasi Komitmen Organisasional Karyawan Perusahaan Swasta di Surabaya Timur. Jurnal Mitra Ekonomi dan Manajemen Bisnis, 2(2), 155-171.

Ghozali, I. (2017). Pengaruh Motivasi Kerja, Kepuasan Kerja dan Kemampuan Kerja Terhadap Kinerja Pegawai Pada Kantor Kementerian Agama Kabupaten Banjar. Jurnal Ilmiah Ekonomi Bisnis, 3(1). 